\title{
ANALISIS KOTA JAKARTA SEBAGAI SMART CITY DAN PENGGUNAAN TEKNOLOGI INFORMASI DAN KOMUNIKASI MENUJU MASYARAKAT MADANI
}

\author{
Endang Puji Astutik ${ }^{\star}$, Gunartin ${ }^{\star *}$ \\ Email: dosen01682@Unpam.ac.id, dosen01339@unpam.ac.id
}

\begin{abstract}
ABSTRAK
ANALISIS KOTA JAKARTA SEBAGAI SMART CITY DAN PENGGUNAAN TEKNOLOGI INFORMASI DAN KOMUNIKASI MENUJU MASYARAKAT MADANI. Penelitian ini bertujuan untuk menganalisa dan mendeskripsikan perkembangan Jakarta Smart Cityter masuk keunggulan-keunggulan dan kekurangan dari Jakarta Smart City yang dikaitkan dengan penggunaan teknologi informasi dan komunikasi untuk menuju masyarakat madani setelah berjalan empat tahun lebih. Metode yang digunakan dalam penelitian ini adalah metode kualitatif dengan pendekatan analisa deskriptif. Penelitian ini menggunakan teknik analisa deskritif dari data yang telah dikumpulkan. Teknik pengumpulan data menggunakan data sekunder yaitu dari web site Jakarta Smart City Go. Id dan data primer melalui wawancara langsung dengan nara sumber yaitu divisi Jakarta Smart City (JSC). Hasil penelitian menunjukkan bahwa pelaksanaan komponen-komponen Jakarta Smart City seperti smart mobility, smart government, smart economy, smart environment, smart living dan smart people sudah berjalan baik serta sangat terintegrasi dengan penggunaan teknologi informasi. Demokrasi, toleransi, pluralisme juga sudah terlihat, keadilan sosial sedang diwujudkan dengan adanya perhatian Pemprov DKI terhadap rakyatnya. Begitu pula dengan berdirinya lembaga swadaya masyarakat, pers, dan partai politik bahwa setiap warga Jakarta berhak menyalurkan aspirasinya. Dari hasil penelitian dapat disimpulkan perkembangan Jakarta Smart City yang sekarang sudah baik, hubungan dengan penggunaan Teknologi Informasi sangat erat, sedangkan kekurangan dari Jakarta Smart City yaitu perkembangan inovasi teknologi informasi lebih cepat dibandingkan dengan regulasi artinya jika ada inovasi teknologi yang terkini belum bisa langsung dijalankan, harus melalui sistem regulasi anggaran. Tatanan Masyarakat Madani di kota Jakarta sudah terlihat dengan tandai banyaknya pembangunan wilayah publik yang luas serta bebas berpolitik tanpa adanya tekanan. Pemerintah, swasta dan masyarakat sudah terjalin kerjasama dalam pembangunan Jakarta yang lebih inovatif dan transparan.
\end{abstract}

Kata Kunci : Smart City, Teknologi Informasi dan Komunikasi, Masyarakat Madani

\begin{abstract}
ANALYSIS OF JAKARTA CITY AS A SMART CITY AND THE USE OF INFORMATION AND COMMUNICATION TECHNOLOGY TOWARDS MADANI COMMUNITIES. This study aims to analyze and describe the development of Jakarta Smart Cityter into the advantages and disadvantages of Jakarta Smart City which is associated with the use of information and communication technology to go to civil society after more than four years. The method used in this study is a qualitative method with a descriptive analysis approach. The results showed that the implementation of Jakarta Smart City components such as smart mobility, smart government, smart economy, smart environment, smart living and smart people had gone well and was very integrated with the use of information technology. Democracy, tolerance, pluralism have also been seen, social justice is being realized with the attention of the DKI Jakarta Provincial Government to its people. From the results of the study it can be concluded that the development of Jakarta Smart City is now good, the relationship with the use of Information Technology is very close, while the shortcomings of Jakarta Smart City are the development of information technology innovation faster than the budget regulation system. The Civil Society Order in the city of Jakarta has been seen by marking the development of large areas of public and political freedom without any pressure. Cooperation between the Government, the private sector and the community in the development of Jakarta has been well established, more innovative and transparent.
\end{abstract}

Keywords: Smart City, Information and Communication Technology, Civil Society

*) dan ${ }^{* *}$ ) Dosen S1 Manajemen, Fakultas Ekonomi, UNPAM 


\section{PENDAHULUAN}

\section{A. Konteks Penelitian}

Kota Jakarta merupakan kota metropolitan yang padat akan penduduk, yang begitu sibuk dengan hiruk-pikuk, hilir-mudik manusia dan padat lalu lintas ibarat kota yang tak pernah mati. Selain sebagai kota metropolitan Jakarta juga sebagai ibu kota negara Indonesia. Dengan predikat Jakarta sebagai kota metropolitan dan ibu kota negara maka kota ini menjadi pusat kegiatan perkantoran, pemerintahan maupun swasta. Niaga dan bisnis merupakan bagian dari kehidupan warga Jakarta dan sekitarnya.

Dengan banyak disandangnya predikat tersebut maka sudah sewajarnya kota Jakarta harus diatur dan dikelola dengan baik yang saat ini Pemerintahan Provinsi DKI Jakarta mengimplementasikan pembangunan kota Jakarta sebagai smart city. Jika seluruh komponen Smart city sudah bisa diterapkan dengan baik maka kota Jakarta bisa dikategorikan ke dalam masyarakat madani artinya Jakarta smart city merupakan wujud dari implementasi masyarakat madani. Karena ciri-ciri masyarakat madani diantaranya, peradaban adalah manusia cerdas yang tinggal diperkotaan artinya masyarkatnya sudah terintegrasi dengan baik mulai dari pendidikan, ekonomi, sosialbudaya dan kesadaran beragama. Karena ciri-ciri smart city diantaranya penggunaan atau pemanfaatan teknologi informasi dan komunikasi yang merupakan aspek penting yang nantinya diharapkan dapat memperbaiki kualitas pelayanan pemerintah kota untuk menghasilkan proses kerja yang lebih efektif dan efisien.

Pembangunan yang saat ini dilakukan pemerintah provinsi Jakarta luar biasa, mulai pembangunan infrastruktur termasuk jalan, jembatan, terowongan, rel kereta bawah tanah, bandara, pelabuhan, pengelolaan gedung. Terlebih era kepemimpinan Pak Anis Bawesdan bersama Sandiaga Uno kala itu fokus memperbaiki segala sektor mulai infrastruktur, ekonomi, sosial dan budaya. Kota Jakarta memiliki permasalahan yang terus bertambah dalam penataan ruangnya karena semakin lama penduduk Jakarta semakin bertambah hal ini disebabkan tidak hanya dari pertumbuhan penduduk lokal saja tapi juga adanya urbanisasi dari tempat lain. Terkadang masalah itu muncul akibat dari pembangunan kota itu sendiri. Agar dapat mengontrol dan mencegah hal tersebut tidak terjadi maka diperlukan sebuah kebijakan yang smart dengan manajemen kota yang tepat sasaran melalui pendekatan konsep perencanaan dan pengelolaan yang berkelanjutan.

Konsep smart city telah memboming untuk pembangunan kota-kota besar di seluruh Indonesia termasuk kota Jakarta telah mengimplementasikan konsep ini, namun belum semua kota bisa mewujudkan seutuhnya. Bagian terpenting dari smart city atau kota cerdas adalah bahwa kota saat ini harus memberikan pelayanan yang menggunakan teknologi terkini dan membangun infrastruktur yang pintar, sehingga dapat memberikan pelayanan yang efektif, efisien dan ekonomis kepada seluruh masyarakat yang tinggal di kota ( Sudaryono, 2014). Dengan begitu masyarakat D.K.I akan merasa puas atas pelayanan yang diberikan pemprov D.K.I Jakarta.

Kota-kota yang disebut smart city adalah kota yang pada awalnya memiliki terobosan baru dalam penyelesaian-penyelesaian masalah di kotanya, dan sukses meningkatkan performa kotanya (Widyaningsih, 2013). Jakarta smart city harusnya 
memiliki 8 indikator yaitu smart governance (pemerintahan yang transparan, informatif dan responsif), smart economy (menumbuhkan produktivitas dengan kewirausahaan dan semangat inovasi), smart people (peningkatan kualitas SDM dan fasilitas hidup layak), smart mobility (penyediaan system transportasi dan infrastuktur), smart environment (manajemen sumber daya alam yang ramah lingkungan), dan smart living (mewujudkan kota sehat dan layak huni), smart operation center (mengelola dan menjamin kinerjanya melalui jaringan telekomunikasi dan infrastruktur IT guna memberikan kualitas pelayanan yang baik yang diperlukan kliennya), smart service Meluncurkan aplikasi smart service yang bisa diakses melalui telepon pintar, masyarakat dapat mengakses berbagai layanan termasuk keluhan ataupun permohonan perizinan hingga layanan kegawatdaruratan.

Letak Geologis, seluruh dataran terdiri dari endapan Pleistocene yang terdapat pada $\pm 50 \mathrm{~m}$ dibawah permukaan tanah. Bagian selatan terdiri atas lapisan alluvial, sedang dataran rendah pantai merentang ke bagian pedalaman sekitar $10 \mathrm{Km}$. Di wilayah bagian utara baru terdapat pada kedalaman 10-25, makin ke selatan permukaan tanah yang keras dengan kedalaman $40 \mathrm{~m}$.

Keadaan Kota Jakarta umumnya beriklim panas dengan suhu udara maksimum berkisar $32,7^{\circ} \mathrm{C}-34^{\circ} \mathrm{C}$ pada siang hari. Dengan uraian latar belakang diatas maka penulis tertarik untuk mengadakan penelitian yang berjudul "Analisis Kota Jakarta SebagaiSmart City dan Penggunaan Teknologi Informasi dan Komunikasi Menuju Masyarakat Madani"

\section{B. Perumusan Malasah}

Berdasarkan latar belakang masalah yang telah diuraikan diatas maka rumusan masalah pada penelitian ini adalah :

1. Bagaimana deskripsi analisis pekembangan kota Jakarta sebagai smart city setelah berjalan empat tahun?

2. Bagaimana deskripsi pemanfaatan tehnologi informatika dan komunikasi menuju masyarakat madani?

3. Bagaimana korelasi antara analisis kota Jakarta sebagai smart city dengan pemanfaatan teknologi Informatika, Komunikasi serta beberapa faktor keunggulan dan kekurangannya setelah berjalan empat tahun untuk menuju Masyarakat Madani?

\section{Tujuan Penelitian}

Untuk memberikan gambaran dan analisa dekriptif tentang tujuan Jakarta Smart City yaitu mewujudkan Jakarta yang baru, informatif, transparan disertai kolaborasi penggunaan teknologi supaya pelayanan publik menjadi lebih baik merupakan misi Jakarta Smart City (JSC). Hal itu tentu membutuhkan waktu dan proses untuk mewujudkannya dan hal ini tentu ada beberapa faktor kelebihan dan kekurangan dari program Jakarta Smart City tersebut. Untuk itu tujuan penelitian ini adalah untuk mengalisa dan mendiskripsikan faktor-faktor keunggulan dan kekurangan dari program Jakarta Smart City yang dikaitkan dengan penggunaan teknologi informasi dan komunikasi untuk menuju masyarakat madani setelah berjalan empat tahun lebih. 


\section{TINJAUAN PUSTAKA}

\section{A. GAMBARAN UMUM KOTA DKI JAKARTA}

1. Visi dan Misi Pemerintah Provinsi DKI Jakarta

Membangun dan mengelola Kota Jakarta yang baru dan informatif memerlukan strategis perencanaan jangka panjang yang matang dan tata kelola pemerintahan yang transparan, Jakarta kota maju, lestari dan berbudaya yang warganya terlibat dalam mewujudkan keberadaban, keadilan dan kesejahteraan bagi semua yang didasarkan pada visi dan misi.

a. VISI

Terwujudnya Jakarta sebagai kota maju, lestari dan berbudaya yang warganya terlibat dalam mewujudkan keberadaban, keadilan dan kesejahteraan bagi semua.

b. MISI

1) Menjadikan Jakarta kota yang aman, sehat, cerdas, berbudaya dengan memperkuat nilai-nilai keluarga dan memberikan ruang kreatifitas melalui kepemimpinan yang melibatkan, menggerakkan dan memanusiakan.

2) Menjadikan Jakarta kota yang memajukan kesejateraan umum melalui terciptanya lapangan kerja, kestabilan dan keterjangkauan kebutuhan pokok, meningkatnya keadilan sosial, percepatan pembangunan infrastruktur, kemudahan investasi dan berbisnis, serta perbaikan pengelolaan tata ruang.

3) Menjadikan Jakarta tempat wahana aparatur Negara yang bekarya, mengabdi, melayani, serta menyelesaikan berbagai permasalahan kota dan warga, secara efektif, meritokratis, dan berintegritas.

4) Menjadikan Jakarta kota yang lestari dengan pembangunan dan tata kehidupan yang memperkuat daya dukung lingkungan dan sosial.

5) Menjadikan Jakarta kota yang dinamis sebagai simpul kemajuan Indonesia yang bercirikan keadilan, kebangsaan dan kebinekaan.

\section{Batas Wilayah}

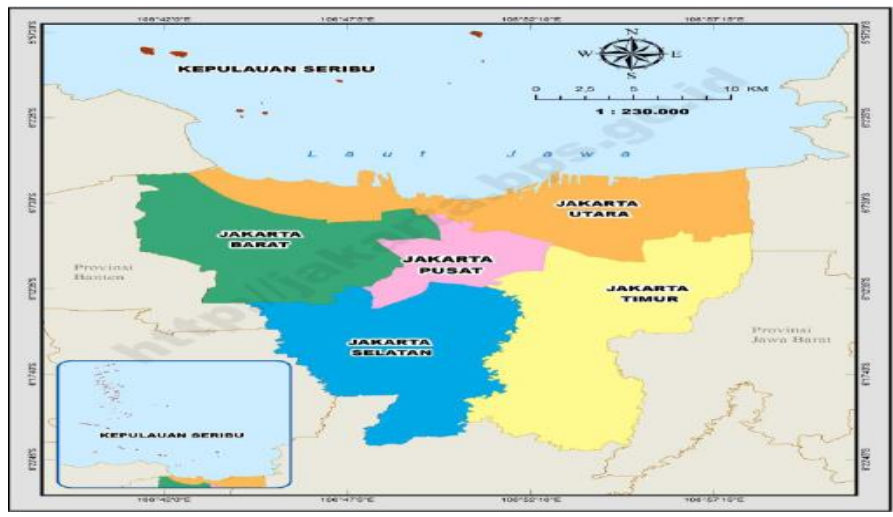

Sumber: Almaida-Medina.blokspot.com

Batasan wilayah DKI Jakarta

Sebelah Selatan : Kota Depok

Sebelah Timur : Provinsi Jawa Barat

Sebelah Barat : Provinsi Banten

Sebelah Utara : Laut Jawa 


\section{Demografi}

Total penduduk Jakarta berdasarkan hasil survei tahun 2015 adalah 10.177.924 jiwa dengan kepadatan 15.367 jiwa per kilometer persegi. Rata-rata pertumbuhan penduduk adalah bertambah 1,02 persen dibandingkan dengan tahun sebelumnya. .

\section{Ekonomi}

Pertumbuhan Ekonomi Jakarta pada triwulan pertama tahun 2018 menunjukkan angka sebesar $0,51 \%$ bila dibandingkan dengan triwulan sebelumnya. Dilihat dari sisi pengeluaran, pertumbuhan tertinggi dicapai komponen ekspor yang tumbuh sebesar $14,11 \%$.

\section{Sosial Budaya}

Dahulu masyarakat Jakarta (Betawi) jika ingin mengawinkan putra/putrinya masih berbau kerabat dengan tujuan supaya hartanya tidak jatuh ke orang lain. Namun seiring berjalannya waktu adat istiadat itu mulai meredup kini mereka kaum Betawi sudah berbaur diperbolehkan menikah dengan siapa saja dan dari suku mana saja.

\section{B. Smart City}

\section{Definisi Konsep Smart City}

Jika menurut Nijkamp et al (2009) dalam Widyaningsih (2013) tentang definisi kota cerdas adalah kota yang mampu menggunakan sumber daya manusia (SDM), modal sosial, dan infrastruktur telekomunikasi moderen untuk mewujudkan pelabuhan ekonomi berkelanjutan dan kualitas kehidupan yang tinggi, dengan manajemen sumber daya yang bijaksana melalui pemerintahan berbasis partisipasi masyarakat. Sedangkan Cohen (2011) menyebutkan bahwa kota cerdas diidentifikasikan pada 6 (enam) dimensi utama yaitu smart government (pemerintahan cerdas), smart economy (ekonomi cerdas), smart society (kehidupan social cerdas), smart mobility ( mobilitas cerdas), smart environment (lingkungan cerdas), dan quality of life (hidup berkualitas). Pengertian dimensi mobilitas cerdas pada sebuah kota cerdas lebih menekankan pada pergerakan yang mudah. Hal tersebut dijamin oleh kemampuan inovatif dan berkelanjutan dan transportasi umum serta penggunaan kendaraan dengan dampak lingkungan yang rendah (Alberti, 2011) yang diantara 6 komponen smart city diterapkan untuk mewujudkan kenyamanan warga DKI dan sekitarnya.

Smart city adalah kota dengan investasi modal manusia dan sosial, dengan transportasi (tradisional) dan infrastruktur komunikasi modern serta pembangunan ekonomi yang berkelanjutan dan kualitas hidup yang tinggi, dengan manajemen sumber daya alam (SDA) yang bijaksana melalui tata pemerintahan yang partisipatif, (Giffinger 2010) dalam (Jung Hoon 2014)

\section{Penelitian Terdahulu}

\section{Tabel : 2.1 : Penelitian Terdahulu}

\begin{tabular}{|l|l|l|l|l|}
\hline No. & \multicolumn{1}{|c|}{$\begin{array}{c}\text { Penulis, tahun dan } \\
\text { Judul }\end{array}$} & $\begin{array}{c}\text { Metode } \\
\text { Penelitian }\end{array}$ & $\begin{array}{l}\text { Teknik } \\
\text { Pengumpulan } \\
\text { dan analisa data }\end{array}$ & \multicolumn{1}{|c|}{ Hasil Penelitian } \\
\hline 1. & $\begin{array}{l}\text { Hafed Chourabi, Tae } \\
\text { woo Nam, Shawan } \\
\text { Walker, J Ramon Giil } \\
\text { Carcia, Sehl Mellouli, }\end{array}$ & $\begin{array}{l}\text { Studi Pustaka } \\
\text { dan deskriptif } \\
\text { kualitatif }\end{array}$ & $\begin{array}{l}\text { Konsep smart city } \\
\text { dipahami melalui kerang- } \\
\text { ka /ruang lingkup yang di } \\
\text { pengaruhi 2 faktor yaitu }\end{array}$ \\
\hline
\end{tabular}




\begin{tabular}{|c|c|c|c|c|}
\hline & $\begin{array}{l}\text { Karine Nahon, Theresa } \\
\text { A. Pardo, dan Han } \\
\text { Jochens School, } 2012 . \\
\text { Understanding Smart } \\
\text { City an integrative } \\
\text { frame work }\end{array}$ & & & $\begin{array}{l}\text { faktor luar dan dalam. } \\
\text { Faktor dari dalam yaitu } \\
\text { pemerintah, infrastruktur } \\
\text { dan ekonomi sedangkan } \\
\text { dari luar adalah faktor } \\
\text { teknologi, pengelolaan } \\
\text { dan kebijakan. }\end{array}$ \\
\hline 2. & $\begin{array}{lr}\text { Anggraini \& } & \text { Rahmawati } \\
2017 . & \text { Penentuan } \\
\text { Variabel Berpengaruh } \\
\text { Terhadap Pengemba- } \\
\text { ngan Kampung Cerdas } \\
\text { Dalam Mewujudkan } \\
\text { Smart City }\end{array}$ & Kualitatif & $\begin{array}{l}\text { Literatur, FGD, } \\
\text { Kuisioner dengan } \\
\text { teknis analisis } \\
\text { deskritif kualitatif. }\end{array}$ & $\begin{array}{l}\text { Terdapat Variabel ber- } \\
\text { pengaruh sesuai konsep } \\
\text { smart city, yang mana } \\
\text { variabel berpengaruh } \\
\text { menyesuaikan karakter } \\
\text { kampong perkotaan dan } \\
\text { masyarakat didalamnya. }\end{array}$ \\
\hline 3. & $\begin{array}{lr}\text { Wahyudi dan } & \text { Hariadi, } \\
2016 . & \text { Strategi } \\
\text { Pembangunan } & \\
\text { smartcity } & \text { dan } \\
\text { tantangannya } & \text { bagi } \\
\text { masyarakat kota. } & \end{array}$ & Kualitatif & $\begin{array}{lr}\text { Studi Pustaka, } \\
\text { wawancara dan } \\
\text { analisa data } \\
\text { deskriptif kualitatif }\end{array}$ & $\begin{array}{l}\text { Tantangan diterapkan- } \\
\text { nya smart city di suatu } \\
\text { daerah antara lain ke- } \\
\text { tersediaan data dan } \\
\text { informasi, keamanan dan } \\
\text { privasi, investasi yang } \\
\text { sangat besar, infrastruk- } \\
\text { tur IT adaptasi social dan } \\
\text { pengem-bangan aplikasi. }\end{array}$ \\
\hline
\end{tabular}

\section{Indikator Jakarta Smart City}

Di bawah ini penulis akan menguraikan beberapa indikator smart city yang didasarkan gambar Jakarta smart city yang tersebut diatas sebagai berikut:

1. Smart Living, yaitu yang menunjukkan pada kualitas hidup dan kebudayaan masyarakat, karena ada kemudahan akses terhadap layanan pendidikan, layanan kesehatan, pengembangan peran media, tersedianya semua kebutuhan, adanya rasa aman, keselamatan, kemudahan dan kenyamanan hidup.

2. Smart Mobility, akses moda transportasi yang beragam dan memprioritaskan angkutan yang ramah lingkungan dan bukan kendaraan bermotor, terintegrasi dengan teknologi informasi dan komunikasi.

3. Smart Governance, peran pemerintah yang mengeluarkan kebijakan dengan mengindahkan prinsip-prinsip supremasi hukum, kemanusiaan, keadilan, demokrasi, partisipasi, transparansi, profesionalitas, dan akuntantabilitas serta efektvitas dan efisiensi kebijakan. Termasuk pengembangan e-governance dan penggunaan teknologi informasi dan komunikasi sehingga masyarakat bisa berpartisipasi dalam perencanaan, pelaksanaan dan pengawasan pembangunan.

4. Smart Economy, Menunjukkan keadaan tingkat ekonomi dan kesejahteraan finansial masyrakat yang tinggi dengan pertumbuhan ekonomi yang baik dan pendapatan perkapita tinggi. Semakin banyaknya wirausaha bahkan pengembangan city branding, produktifitas secara lokal dan global.

5. Smart Environment, adanya perencanaan pembangunan yang ramah lingkungan, energi ramah lingkungan, bangunan ramah lingkungan disertai penerapan dan pemanfaatan pengelolaan lingkungan berbasis IT, pengelolaan sumber daya alam berbasis IT serta pengembangan sumber energy baru. Lingkungan yang 
memberikan kenyamanan dimasa kini dan masa mendatang dengan kata lain keberlanjutan lingkungan baik dalam keadaan fisik maupun non fisik.

6. Smart People, masyarakatnya berpendidikan bagus di era abad 21 baik secara formal maupun non formal dan mampu mengembangkan sumber daya manusia yang melek teknologi. Dukungan terhadap penelitian pengembangan karakter sosial budaya semakin kuat. Sumberdaya manusia yang inovatif dan kreatif, masyarakatnya inklusif.

Menurut penulis harusnya komponen Jakarta smart city ditambah 2 lagi sebagai berikut:

7. Smart Service, Menyediakan dan memberikan pelayanan dengan cepat serta memuaskan baik melalui aplikasi smart service yang bisa diakses melalui telepon pintar, email atau pesan singkat. Aplikasi ini masyarakat dapat mengakses berbagai layanan, penyampaian keluhan, permohonan izin hingga layanan kegawatdaruratan.

8. Smart Operation Center, Mengelola, menjamin seluruh kinerjanya dengan jaringan telekomunikasi dan infrastruktur IT untuk memberikan kualitas layanan yang tertinggi yang diperlukan kliennya, melalu pusat operasi cerdas mengoperasikan automatic meter infrastruktur mendatang untuk air, gas, limbah dan lain-lain.

Ada 3 (tiga) dimensi utama yang sangat mendukung di dalam smart city diantaranya yaitu Teknologi, People, dan Community

\section{Konsep Penggunaan Teknologi Informasi dan Komunikasi}

Definisi teknologi informasi berkaitan dengan perangkat keras dan perangkat lunak untuk menjalankan satu atau sejumlah tugas pemrosesan data seperti menangkap, mentransmisikan, menyimpan, memgambil, memanipulasi, dan menampilkan data (Alter, 1992). Teknologi Informasi tidak hanya terbatas pada teknologi komputer (hardware \& software) yang digunakan untuk memproses dan menyimpan informasi, melainkan juga mencakup teknologi komunikasi untuk mengirimkan informasi (Martin 1999). Teknologi informasi adalah segala bentuk teknologi yang diterapkan untuk memproses dan mengirimkan infromasi dalam bentuk elektronis (Lucas, 2000). Definisi teknologi informasi tidak hanya terbatas pada teknologi komputer (perangkat keras dan perangkat lunak) yang digunakan untuk memproses dan menyimpan informasi, melainkan juga mencakup teknologi komunikasi untuk mengirimkan informasi. (Martin, 2002). Jika penulis simpulkan definisi teknologi informasi adalah gabungan antara teknologi komputer dan teknologi telekomunikasi yang digunakan dalam penangkapan, penyimpanan, dan penyebaran informasi. Teknologi informasi dapat digolongkan menjadi 2(dua) bagian, yaitu: perangkat lunak (Software) dan perangkat keras (Hardware). Sedangkan yang tergolong perangkat keras yaitu peralatan-peralatan yang bersifat fisik seperti memory, printer, dan keyboard. Perangkat lunak terkait dengan instruksi-instruksi untuk mengatur perangkat keras agar bekerja sesuai dengan tujuan instruksi-instruksi tersebut., pemroses Teknologi masukan adalah segala perangkat yang digunakan untuk menangkap data/informasi dari sumber asalnya. Untuk mengeluarkan informasi diperlukan perangkat lunak atau program. Program adalah sekumpulan instruksi yang 
digunakan untuk mengendalikan perangkat keras komputer. Teknologi penyimpan menyangkut segala peralatan yang digunakan untuk menyimpan data. Contoh media penyimpan data adalah tape, hard disk, disket dan zip disk. Teknologi telekomunikasi adalah teknologi yang menghubungkan informasi jarak jauh. Sebagai contoh dari teknologi infromasi dan komunikasi adalah Internet dan ATM. Sedangkan komponen CPU merupakan mesin pemroses yang penting dalam teknologi informasi yang berfungsi untuk mengingat data/program (berupa komponen memory).

\section{E. Konsep Masyarakat Madani}

Masyarakat Madani menurut bahasa Inggris dikenal dengan istilah civil society. Civil society memiliki pengertian suatu masyarakat yang mimiliki peradaban tinggi dalam membangun, menjalani, dan memaknai kehidupannya. Kata madani sendiri berasal dari bahasa Arab yaitu Madinah yang artinya kota, hal ini mengacu pada konsep negara kota Madinah yang dibangun Nabi Muhammad SAW pada tahun 622M. Konsep masyarakat Madani juga mengacu pada konsep tamadhun yaitu masyarakat yang memiliki peradaban, konsep ini diperkenalkan oleh Ibn Khaldun dan konsep AlMadinah Al-Fadhilah (Madinah sebagai negara utama) hal ini diungkapkan oleh filsuf Al-Farabi pada abad pertengahan. Jika penulis simpulkan pengertian masyarakat madani menurut para ahli di atas adalah suatu tatanan masyarakat yang tinggal di suatu wilayah yang memiliki kesamaan dengan masyarkat perkotaan disertai peradaban tinggi artinya sudah baik moralnya, sopan-santun, kesadaran dalam ketaatan beragama yang baik dan bisa menerima.

\section{METODE PENELITIAN}

\section{A. Lokasi Penelitian}

Lokasi penelitian merupakan tempat yang digunakan oleh peneliti mencari dan mengumpulkan sumber informasi dan data yang berkaitan dengan fenomena yang akan diteliti. Penelitian ini dilakukan di kota Jakarta yang merupakan ibu kota Jakarta dan dikenal dengan kota metropolitan, khususnya di Pemerintahan Provinsi D.K.I Jakarta.

\section{B. Pendekatan Penelitian}

Metode penelitian yang penulis gunakan adalah pendekatan kualitatif karena dalam penelitian ini penulis menggunakan metode pengumpulan data primer berupa wawancara dan diskusi terfokus dengan para aparat yang berkepentingan yang di temui dilapangan, serta pengamatan langsung berkaitan dengan kegiatan-kegiatan langsung yang berhubungan dengan smart city yang nantinya menghasilkan data deskriptif berupa kata-kata hasil wawancara ataupun pengamatan yang telah penulis lakukan dari para pegawai pemerintah kota DKI Jakarta dan instansi yang terkait seperti dinas komunikasi dan informasi (Diskominfo), dinas tata kota dan pertamanan, perusahaan yang bekerja sama dengan pemerintah dalam mengimplementasikan teknologi, akademisi, lembaga swadaya masyarakat, serta warga masyarakat yang aktif terlibat dalam program smart city. 


\section{Kehadiran Peneliti}

Dalam penelitian ini peneliti bertindak sebagai instrument sekaligus pegumpul data, artinya peneliti bersama team terlibat penuh dalam wawancara, observasi dan studi pustaka serta menganalisa informasi data dari nara sumber juga sumber data yang lain. Oleh karena itu dalam penelitian ini penelti bertindak sebagai partisipan penuh untuk menganalisa komponen-kompenen smart city yang telah dilaksanakan Jakarta Smart City dikaitkan dengan penggunaan Teknologi informasi dan komunikasi menuju Masyarakat Madani.

\section{Jenis Data}

Data yang digunakan dalam penelitian ini fokus kepada komponen-komponen smart city yang sudah atau belum jelas dilaksanakan menurut konsep Jakarta Smart city dikaitkan dengan penggunaan Teknologi Informasi dan Komunikasi menuju Masyarakat Madani. Data yang digunakan ada dua yaitu : Data Primer adalah data yang langsung diperoleh dari narasumber baik lisan ataupun perilaku subjek yang berkaitan dengan relevansi kompetensi. Sedangkan data Sekunder adalah data yang digunakan untuk mendukung data primer berupa dokumen, foto, catatan lain yang dapat dipakai sebagai sumber data (Sugiyono, 2012).

\section{E. Metode Pengambilan Sampel}

\section{Populasi}

Populasi merupakan wilayah generalisasi yang terdiri atas objek/subjek yang mempunyai kualitas dan karakteristik tertentu yang ditetapkan oleh peneliti untuk dipelajari kemudian ditarik kesimpulannya (Sugiyono, 2015). Populasi pada penelitian ini adalah Daerah Khusus Ibukota Jakarta.

\section{Metode Pengambilan Sampel}

Sampel merupakan jumlah karakteristik yang dimiliki oleh populasi tersebut (Sugiyono, 2015). Apabila populasi besar maka peneliti tidak mungkin mempelajari semua karena keterbatasan waktu, dana dan tenaga, sehingga peneliti mengambil dan menggunakan sampel dari populasi.

\section{F. Data dan Sumber Data}

Data yang digunakan dalam penelitian ini dibagi menjadi dua, yaitu data primer dan sekunder. Data primer diperoleh dari wawancara. Data sekunder didapat dari BPS, perpustakaan, internet, dan literature lainnya yang dapat dijadikan bahan rujukan yang berhubungan dengan penelitian yang dilaksanakan.

\section{HASIL PENELITIAN DAN PEMBAHASAN}

\section{A. Hasil Penelitian}

\section{Gambaran Umum Smart City DKI Jakarta}

Kota yang cerdas tidak begitu saja muncul tiba-tiba namun perlu perencanaan, pembangunan dan pengelolaan serta implementasi yang baik dan rapi. Berdasarkan peraturan Gubernur DKI Jakarta no. 280 tahun 2014 organisasi dan tata kerja unit pengelola Jakarta Smart City sudah direncanakan pada RPJMD 2013-2017. 
Berdasarkan perencanaan ini misi pertama adalah tentang kebijakkan smart city Jakarta. Tahapan kedua pelaksanaan program yang terdiri dari penilaian struktur, prosedur dari Jakarta smart city. Tahapan ketiga mengadakan pengawasan program sehingga stakeholder pelaksana kebijakan Jakarta smart city. Selanjutnya penulis akan menjelaskan Wheel Framework Jakarta Smart City yang didalamnya ada 6 komponen yang juga merupakan keunggulan-keunggulan yang sudah dicapai setelah 4 tahun berjalan diantaranya seperti tersebut di bawah ini:

a. Smart Government merupakan keaktifan peran pemerintah Provinsi DKI yang transparan dalam menjalankan kegiatan operasional pemerintahan telah terintegrasi dengan penggunaan teknologi informasi dan komunikasi, tanggap terhadap kepentingan warganya, begitu pula peran serta masyarakat

b. Smart Economy kegiatan yang bisa menumbuhkan produktivitas ekonomi dengan kewirausahaan disertai inovasi baru.

c. Smart Mobility akses media transportasi semakin beragam tersedia untuk massa transportation. seperti bus trans Jakarta ada juga bus way, MRT, LRT, Comuter Line yang semuanya dilengkapi dengan penggunaan teknologi informasi dan komunikasi, sebelum sampai masing-masing stasiun para penumpang sudah diinfomasikan lewat pengeras suara yang keluar otomatis dari mesin dsertai penyebutan nama-nama stasiun jadi para penumpang sudah bisa mempersiapkan diri jika akan keluar menuju ke alamat tujuannya.

d. Smart People adanya peningkatan sumber daya manusia dan terjadi peningkatan penghidupan kearah hidup yang layak.

e. Smart Environment ditunjukkan dengan adanya manajemen sumber daya alam yang ramah lingkungan. seperti bus way yang menggunakan tenaga listrik dan mobil berbahan bakar gas yang ramah lingkungan.

f. Smart Living mewujudkan kota yang sehat dan layak huni. Untuk mewujudkan Kota Jakarta yang smart maka Pemerintah Provinsi DKI berusaha melaksanakan visi dan misi Jakarta Smart City secara maksimal terbukti telah diluncurkan portal resmi yaitu Jakarta.go.id dan Youtube resmi Pemprov DKI dan Application Programming Interface ( API ) bagi pengembang melalui api.Jakarta.go.id.

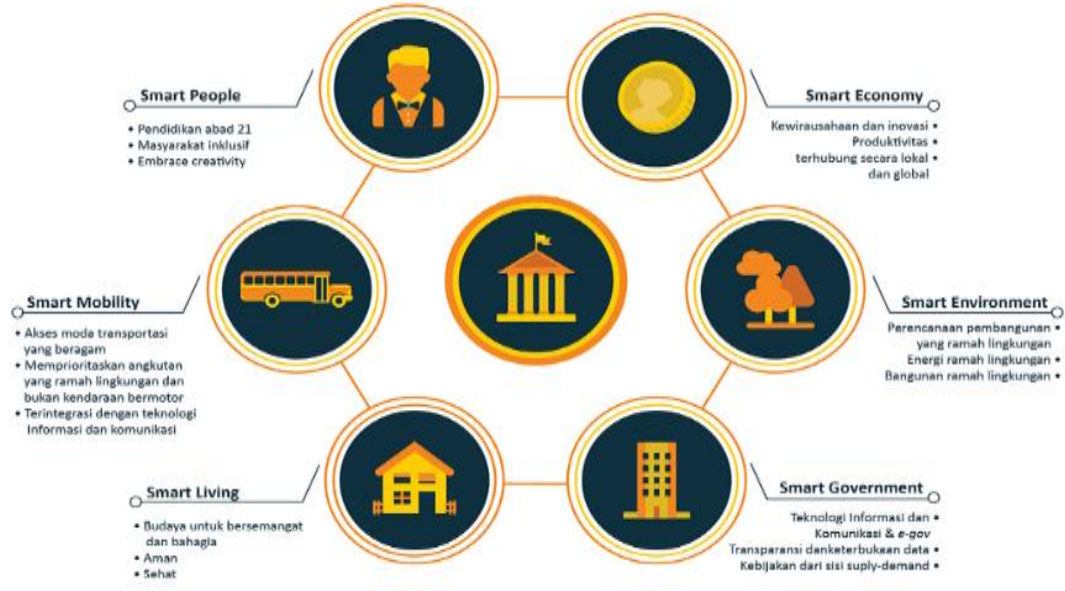

Gambar 3.1: Smart City Wheel Framework

Sumber : Jakarta smart city.go.id 
Kemudian Penulis akan menyajikan diagram gambar yang berkaitan dengan pendekatan sistematis sebagai berikut:

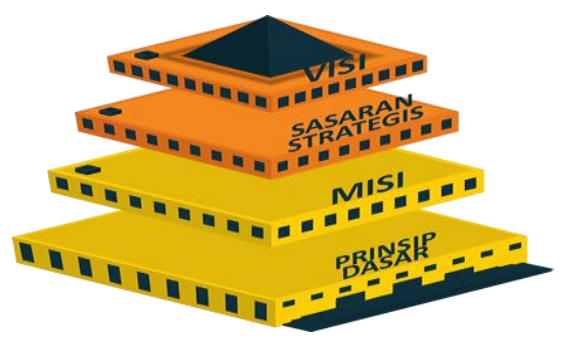

Gambar : 3.2 : Pendekatan Sistematis Smart City Sumber : Jakarta smart city.go.id

Berdasarkan gambar di atas penulis akan menjelaskan tentang pengertian Smart City, visi dan misi dari unit pengelola Jakarta Smart City, sebagai berikut: Pengertian Jakarta Smart City adalah pengaplikasian konsep smart city yang maksimal dengan pemanfaatan teknologi informasi dan komunikasi (TIK) untuk mengetahui, memahami dan mengontrol berbagai sumber daya di suatu kota dengan lebih efektif dan efisien, sehingga dapat memaksimalkan pelayanan publik, memberikan solusi untuk masalah, dan mendukung pembangunan yang berkelanjutan. Sedangkan visi Jakarta Smart City adalah Jakarta Baru yang efisien dan inovatif. Kalau misi Jakarta Smart City adalah mewujudkan Jakarta Baru yang informatif, transparan, serta mendukung kolaborasi menggunakan teknologi untuk pelayanan yang lebih baik.

Menurut Jakarta.go.id keberhasilan Jakarta Smart City bertumpu pada keberadaan dua aplikasi, yaitu Qlue dan Cepat Respon Opini Publik (CROP). Qlue adalah aplikasi yang diperuntukan bagi warga, Sedangkan untuk CROP hanya untuk Pemerintah Provinsi DKI Jakarta dan aparat kepolisian. Selanjutnya penulis akan menjelaskan tentang cara kerja dua aplikasi tersebut. Qlue adalah aplikasi sejenis sosial media yang memiliki sarana untuk menyampaikan aspirasi pengaduan real time. Aplikasi Qlue dapat diunduh secara gratis melalui smartphone yang berbasis Android, lewat Qlue, warga dapat melaporkan semua kejadian seperti macet, banjir, jalan rusak, penumpukkan sampah, ataupun ketersediaan tempat tidur di rumah sakit. Laporan yang disampaikan selain berupa tulisan juga harus berbentuk foto. Laporan yang berasal dari masyarakat tersebut selanjutnya dipetakan secara digital dan terintegrasi dengan laman smartcity.Jakarta.go.id dan CROP. Seluruh aparat Pemprov DKI diwajibkan untuk menginstal aplikasi CROP di smartphone mereka masing-masing, terutama aparat yang bertanggung jawab terhadap wilayah permukiman, yakni lurah dan camat.

\section{B. Pembahasan}

\section{Perkembangan Jakarta Smart City setelah 4 tahun}

Kota Jakarta merencanakan Program Jakarta Smart City sejak Desember 2014. Dikutip dari Jakarta Smart City (JSC) Jakarta.go.id misinya adalah mewujudkan Jakarta baru yang informative, transparan serta dintegrasikan dengan penggunaan teknologi informasi dan komunikasi untuk pelayanan yang lebih baik. 
Setelah 4 tahun lebih sejak didirikan JSC telah bekerjasama dengan beberapa startup untuk memberikan pelayanan dan inovasi yang lebih baik kepada masyarakat. Di akhir tahun 2015 unit pengelola Jakarta Smart City memiliki JSC Lounge yaitu ruangan kretif menuju smart city yang memiliki berbagai ruangan daintaranya Command Center. Ruagan tersebut memiliki LED besar yang menampilkan berbagai informasi yang telah terintegrasi dengan sistem Jakarta Smart City, merupakan pusat komando koordinasi dengan SKPD lainnya terkait kejadian atau permasalahan yang terjadi di Jakarta. Command Center juga dilengkapi dengan video surveillance dan sistem intelegent Operational Center (IOC) berguna memonitoring dan analisis semua kejadian yang ada di Jakarta.

Selanjutnya ruang operasional yang ditempati seluruh pegawai unit pengelola Jakarta Smart City bekerja. Para karyawan bekerja dalam satu ruangan yang dikelilingi kaca transparan yang menyebabkan semua orang bisa melihatnya yang merupakan wujud transparansi Jakaarta dan koordinasi antar tim lebih efektif.

\section{Keunggulan-keunggulan yang telah dicapai Jakarta Smart City setelah 4 tahun.}

Penulis akan menjelaskan keunggulan dari Pelaksanaan Program Jakarta Smart City berdasarkan Wheel FrameworkSmart City yang didalamnya ada 6 komponen diantaranya adalah sebagai berikut;

a. Smart Government merupakan misi yang kelima dengan memperbaiki pelayanan untuk mewujudkan indikator smart governance yaitu dengan membangun pemerintahan yang bersih dan transparan serta berorientasi pada pelayanan publik yang diemban Pemprov DKI Jakarta sesuai RP JMD 2013-2017. Banyak upaya yang telah dilakukan untuk mewujudkan misi ini, diantaran perbaikan pelayanan perizinan dan non-perizinan melalui Pelayanan Terpadu Satu Pintu (PTSP), meningkatkan pelayanan pendidikan dengan Kartu Jakarta Pintar (KJP), juga menigkatkan akses layanan kesehatan dengan bantuan yang disalurkan melalui Jaminan Kesehatan Nasional.

b. Smart Government merupakan keaktifan peran pemerintah Provinsi DKI yang transparan dalam menjalankan kegiatan operasional pemerintahan telah teintegrasi dengan penggunaan teknologi informasi dan komunikasi, tanggap terhadap kepentingan warganya, begitu pula peran serta masyarakat, terbukti dengan adanya dua aplikasi yaitu QLUE dan CROP yang bertujan untuk memberikan pelayanan yang maksimal kepada masyarakat. Menurut Pak Aang divisi monitoring Jakarta Smart City (JSC) bahwa Pemprov DKI khususnya Divisi JSC bekerjasama dengan QLUE (Swasta). Qlue merupakan aplikasi media sosial yang digunakan masyarakat untuk melaporkan permasalahan kota kepada pemerintah, cara kerjanya adalah laporan warga yang masuk melelui aplikasi Qlue akan diteruskan ke pihak terkait dan tetap dipantau perkembangannya melalui aplikasi Qlue di dashboard mycity.qlue.id.

c. Smart Economy merupakan misi pertama dari tahapan-tahapan rencana pembangunan daerah Pemprov DKI Jakarta yaitu mewujudkan Jakarta sebagai kota modern yang tertata rapi serta konsisten dengan tata ruang wilayah. Sesuai dengan 
visi dan misi Jakarta yang terdapat dalam peraturan daerah No. 2 tahun 2013 tentang rencana pembangunan daerah tahun 2013-2017. Visi pembanguanan jangka menengah tersebut adalah Jakarta baru, kota moderen yang tertib dan rapi menjadi tempat hunian yang layak dan manusiawi, memiliki masyarakat yang berkebudayaan, dengan pemerintah yang berorentasi pada pelayanan publik. Adanya pembangunan infrastruktur yang memiliki konsep transit oriented development (TOD) serta memberikan dukungan kepada pembangunan industri teknologi tinggi yang nantinya bisa memperlancar ketercapaian indikator smart economy akibat dari adanya pembangunan kota yang terencana dengan baik, tentu akan mendukung pembangunan ekonomi yang berkelanjutan.

Di Jakarta telah dilaksanakan program OK OC yang artinya one kecamatan one center for entrepreneurship untuk menumbuhkan wirausaha-wirausaha baru. Berdasarkan data yang dihimpun Jawa Pos. Com, di Jakarta terdapat lima OK OCE Mart dan empat Gerai OK OCE. Banyak dan maraknya startup berdiri seperti buka Lapak, OJOL dan lainnya.

d. Smart Mobility merupakan misi yang ke dua yaitu menjadikan Jakarta kota yang bebas dari masalah macet, banjir, sampah dan pemukiman kumuh. Maka dalam hal ini Pemprov DKI Jakarta berusaha mengembangkan dan menggunakan transportasi massal seperti penambahan koridor, armada, dan perbaikkan layanan Transjakarta, serta membangun angkutan umum baru seperti MRT dan LRT hal ini sudah sesuai dengan indikator smart mobility.

Dengan pelaksanaan smart mobility yang baik maka kepindahan seseorang atau sekelompok orang dari tempat satu ketempat lain juga semakin cepat hal ini akan membantu melancarkan urusan orang tersebut terlaksana dengan baik,seperti bus trans Jakarta ataupun bus-way, MRT, LRT, Commuter Line yang semuanya dilengkapi dengan penggunaan teknologi informasi dan komunikasi yang lengkap disertai layar digitalnya, sebelum sampai masing-masing stasiun para penumpang sudah diinfomasikan lewat pengeras suara yang keluar otomatis dari mesin disertai penyebutan nama-nama setiap stasiun jadi para penumpang sudah bisa mempersiapkan diri jika akan keluar menuju ke alamat tujuannya. Bagi para penumpang bus-way sudah bisa mengetahui kapan bus-way akan datang dan terintegrasi dengan mobile transportation application jadi calon penumpang bus-way terhindar dari keresahan dalam menunggu bus way.

e. Smart People yang berkebudayaan merupakan misi yang ke empat yaitu dengan membangun masyarakat perkotaan yang toleren sekaligus mampu dan sadar memelihara kota. Usaha Pemprov DKI Jakarta dengan memperkuat pengembangan budaya Betawi bersinergi dengan budaya multikultur lainnya. Dengan harapan pembangunann kota yang modern tidak meninggalkan budaya asli daerah sekaligus menjaga toleransi antar elemen masyarakat. Dengan terciptanya dan digunakannya transportasi masa yaitu Massa Rapid Transportaiton (MRT), Line Rapid Transportation (LRT) ini menunjukkan adanya smartpeople untuk warga dan pemerintah provinsi Jakarta.

f. Smart Environment untuk mengatasi masalah menahun seperti banjir, pemukiman kumuh dan sampah Pemprov DKI Jakarta berusaha menyediakan hunian publik 
yang layak dan bisa dijangkau harganya oleh warga kota. Untuk mengatasi banjir pemerintah melakukan normalisasi sungai, salah satu upayanya dengan memindahkan mpemukiman penduduk di daerah aliran sungai serta menyediakan hunian public yang layak dengan mendirikan rumah susun. Seperti bus way yang menggunakan tenaga listrik dan mobil berbahan bakar gas yang ramah lingkungan.

g. Smart Living terwujudnya kota yang sehat dan layak huni. Telah dibangunkannya rusun dan perumahan untuk warga DKI Jakarta dengan DP. $0 \%$ ini mengindikasikan adanya keseriusan Pemprov DKI Jakarta untuk merealisasikan bangunan tempat tinggal untuk warga DKI Jakarta yang layak huni. Setiap jalan raya yang di Jakarta rata-rata diharuskan terbangunnya trotoar yang berfungi untuk para pejalan kaki hal ini membuat aman dan nyaman pengguna trotoar tersebut. Untuk pencemaran udara masih tergolong tinggi terutama dari polusi kendaraan bermotor.

\section{Kekurangan-kekurangan dari Jakarta Smart City setelah $\mathbf{4}$ tahun}

a. Smart Government. Di tingkat kelurahan belum maksimalnya pelayanan untuk pembuatan kartu tanda penduduk elektronik (EKTP). Saat putri saya ingin membuat kartu tanda penduduk elektronik (EKTP) masih harus menunggu minimal satu minggu baru bisa jadi, bahkan hingga kini sudah satu bulan lebih belum jadi juga tanpa adanya alasan yang jelas seperti blanko yang terbatas. Sedangkan blanko tentu untuk EKTP yang berwewenang mengeluarkan KEMENDAGRI.

b. Smart Economy. Antara pekembangan teknologi dengan sumber daya manusia (SDM) belum seimbang lebih cepat perkembangan teknologi. Dengan banyaknya alat pembayaran digital tentu meminimalisir uang cash namun antara bank local dan bank asing saling berkompetisi untuk pelayanan e-money ini dan Nampak bank asinglah yang mendominasi, sebagai missal Go-pay. Jika alat pembayaran yang berupa e-money ini mengalir ke bank asing maka bisa dipastikan akan melemahkan bank local sehingga bisa mempengaruhi pertumbuhan ekonomi local dan nasional.

c. Smart Mobility. Kurang sempurnanya pelayanan dari armada bus way terutama di area halte-halte belum tersedia tempat duduk yang maksimal untuk calon penumpang sehingga banyak yang berdiri lama dan mengantri. Matinya layar monitor jadwal datang-keberangkatan bus way di beberapa halte bus way.

d. Smart People. Masih didapatinya preman-preman jalanan yang bertindak sebagai pak ogah yang menganggu pengaturan lalu-lintas.

e. Smart Environment. Untuk pencemaran udara masih tergolong tinggi terutama dari polusi kendaraan bermotor.

f. Smart Living. Masih banyaknya bangunan rumah yang tidak layak huni seperti kontrakkan petakan ini terdapat di kampung pedalaman Jakarta yang padat penduduk

\section{Penggunaan Teknologi Informasi dan Komunikasi}

Di tingkat pemerintahan smart Government di lingkungan kelurahan sudah terintegrasi dengan penggunaan teknologi informasi dan komunikasi, Sebagai contoh: Saat saya pergi ke kantor kelurahan untuk prosedur pertama kali ambil nomor antrian pelayanan yang penomoran ini sudah terhubung dengan Teknologi Informasi dan 
Komunikasi karena pemanggilan dilakukan oleh mesin yang terhubung dengan server computer.

Untuk smart economy juga sangat erat berkaitan dengan teknologi informasi dan komunikasi dengan adanya jaringan-jaringan startup dan digunakannya alat pembayaran digital seperti go-pay.

Begitu pula smart mobility juga terhubung dengan jaringan internet untuk semua kendaraan transportasi baik itu bus way, Massa RapidTransportations MRT, Line Rapid Transportations LRT, setiap halte disambungkan dengan informasi yang terkini tentang jadwal kedatangan dan keberangkatan dari semua transportasi.

\section{Gambaran Masyarakat Madani DKI Jakarta}

Perwujudan masyarakat madani didasarkan pada dua hal yang utama yaitu legitimasi Negara dan terciptanya masyarakat mandiri yang berpijak diatas fondasi moral yang kokoh. (Arifin 1999)

Masyarakat Jakarta taat beragama dan mendapatkan legalitas dari negara dengan adanya sumber hukum tertulis yang menjamin warga negaranya untuk memeluk agamanya masing-masing sesuai dengan kepercayaan dan keyakinannya. Di perkuat dengan landasan hukum UUD 1945 pasal 29 ayat 2 bahwa Negara menjamin setiap pemeluk agama. Masyarakat Jakarta sudah mandiri secara ekonomi ditandai banyaknya wirausaha-wirausaha baru yang tumbuh subur di setiap sudut wilayah perkotaan. Dengan demikian masyarakat Jakarta sudah semakin sadar pentingnya fondasi agama sehingga memunculkan moral yang baik, serta sadar untuk hidup mandiri dengan berwiraswasta.

Masyarkat Jakarta sudah terintegrasi dengan individu-individu dan kelompokkelompok eksklusif ke dalam masyarakat dengan kontak sosial dan aliansi sosial.Terjembataninya kepentingan-kepentingan individu dan negara karena adanya masukan dari keanggotaan organisasi-organisasi volunteer yang bisa mempengaruhi keputusan pemerintah. Sudah meluasnya kesetiaan dan kepercayaan sehingga tidak individualis. Masyarakat bebas mengikuti lembaga-lembaga sosial dengan berbagai perspektif. Di kota Jakarta juga sudah terlihat unsur-unsur masyarakat madani dengan adanya wilayah publik yang luas bebas menentukan pilihan politiknya tanpa rasa takut. Demokrasi, toleransi, pluralisme juga sudah terlihat, keadilan sosial sedang diwujudkan dengan adanya perhatian Pemprov DKI terhadap rakyatnya. Begitu pula dengan berdirinya lembaga swadaya masyarakat, pers, dan partai politik bahwa setiap warga Jakarta berhak menyalurkan aspirasi politiknya tanpa adanya intervensi dari pihak lain.

\section{Hasil wawancara Peneliti dengan Nara Sumber Divisi Monitoring JSC.}

Pada hari Senin, 24 Juni 2019 Peneliti datang ke kantor Pemprov DKI Jakarta yang sering dikenal dengan Balai kota Jakarta, dan bertemu langsung dengan bagian Monitoring Jakarta Smart City (JSC) yang bernama bapak Aang Jatmika di ruangan Jakarta Smart City. Menurut Pak Aang yang menginisiasi gedung Jakarta Smart City yang dikenal dengan JSC Lounge adalah Presiden Joko Widodo yang diresmikan pada akhir tahun 2015 sekaligus luancing Jakarta Smart City. Unit JSC ini juga bekerjasama dengan pemerintah dan berbagai pihak swasta yang memiliki tugas mengintergrasikan data dalam hal ini JSC berhak menarik data-data yang terkait dengan enam prinsip 
Jakarta Smart city dari masing-masing dinas baik pemerintah ataupun swasta, yang kemudian dianalisisnya. Data-data yang ditarik bersifat umum bukan darurat. Untuk Smart mobility yang mengerjakan secara teknis adalah Dinas perhubungan bekerjasama dengan Trans Jakarta di bawah naungan PEMDA. Dinas ini memiliki profesional transformasi, seluruh armada merah transjakarta yang berasal dari Tiongkok diganti dengan armadaTtrans Jakarta yang berasal dari Eropa yang dianggap layak dan lebih baik dari armada sebelumnya. Armada Trans Jakarta ini juga bisa dilihat dari aplikasi sehingga keberadaanya bisa dipantau mulai dari halte Monas dan seterusnya, kondisi kemacetan Jakarta juga bisa disajikan melalui aplikasi transportasi umum Jakarta, selain itu juga Trans Jakarta bekerjasama dengan Google Maps Transit sehingga melalui smart phone posisi bus Trans Jakarta bisa diketahui para calon penumpang. Ada 6 aplikasi yang bisa di download berkaitan dengan transportasi umum Jakarta adalah KRL Acces, Trafi, Uber, Gojek dan Grab hal ini berguna untuk menghindari kemacetan di Jakarta.

Selanjutnya peneliti juga bertanya tentang smart environment yang berkaitan dengan bank sampah, ternyata dibawah pengelolaan Dinas Lingkungan Hidup dan Sumber Daya Alam (SDA) sebagai induk pelaksananya, unit JSC hanya mengambil data. Kemudian peneliti juga bertanya tentang aplikasi smart phone yang berkaitan dengan kesehatan menurut pak Aang Jatmika sampai saat ini belum ada karena untuk pelaksanaan tehnisnya ada di Dinas Kesehatan. Jika belum ada disposisi untuk anggaran pembuatan aplikasi kesehatan maka juga belum bisa dilaksanakan.Tetapi untuk mengetahui tempat tidur kosong di rumah sakit Jakarta sudah bisa dilihat secara on-line. Kemudian peneiti juga bertanya tentang smart government khususnya berkaitan dengan pembuatan KTP secara on-line, sekali lagi secara tehnisnya ada di Dinas Kependudukan dan Catatan Sipil (Disdukcapil) khususnya tingkat kelurahan. Selanjutnya peneliti juga bertanya tentang CCTV, berdasarkan informasi yang peneliti terima dari nara sumber bahwa JSC mengintegrasikan 7000 CCTV yang dimilki oleh berbagai institusi baik pemerintah maupun swasta, sehinga jika terjadi kerusakan menjadi tanggung jawab dari masing-masing instansi tersebut. Delegasi-delegasi dari suatu Negara yang pernah berkunjung ke JSC adalah New Zealand dan Ukraina.

\section{KESIMPULAN DAN SARAN}

\section{A. Kesimpulan}

Berdasarkan hasil analisa data yang diperoleh dari turun lapangan maka peneliti dapat menarik kesimpulan bahwa perkembangan Jakarta Smart Citysudah baik, Penggunaan Teknologi Informasi dan Komunikasi setelah Empat Tahun menuju Masyarakat Madani terdapat hubungan yang sangat erat, ada beberapa keunggulan yang dicapai dan ada juga beberapa kekurangannya, antara lain sebagai berikut;

1. Beberapa Keunggulan Jakarta Smart City antara lain sebagai berikut;

a. Smart Mobilitypelaksanaannya sudah baik karena kepindahan seseorang atau sekelompok orang dari tempat satu ketempat lain juga semakin cepat.

b. Smart Goverenmentperan pemerintah Provinsi DKI sudah aktif, transparan, terintegrasi dengan penggunaan teknologi informasi dan komunikasi dalam 
menjalankan kegiatan operasional pemerintahan, tanggap terhadap kepentingan warganya, begitu pula peran serta masyarakat, terbukti dengan adanya dua aplikasi yaitu QLUE dan CROP yang bertujan memberikan pelayanan terbaik.

c. Smart Economy mulai bermunculannya start up melalu perdagangan on-line seperti Bukalapak dan lain-lain.

d. Smart Environment sudah dibangunnya trotoar-trotoar baru untuk pejalan kaki di kota Jakarta, disetiap sector dibangun dan dikembangkan taman dan tempat bermain anak yang sebagian juga dilengkapi dengan CCTV dan security.

e. Smart Living, sudah disediakannya hunian publik yang layak huni dengan harga terjangkau dengan DP $0 \%$.

f. Smart People, sudah dikembangkan dan digunakannya Massa Rapid Transportation (MRT) dan Line Rapid Transportation (LRT).

2. Kekurangan dari Jakarta Smart City yaitu perkembangan antara inovasi perkembangan teknologi informasi dan regulasi ternyata lebih cepat perkembangan inovasi teknologinya artinya jika ada inovasi teknologi yang terkini belum bisa langsung dijalankan harus melalui sistem regulasi anggaran. Begitu pula dengan kesiapan SDM para aparat, JSC masih membutuhkan strategi untuk menyampaikan inovasi teknologi terkini harus pelan-pelan dan membutuh waktu.

\section{B. SARAN}

1. Dibutuhkan sinergitas semua elemen yang untuk menjalankan program Jakarta Smart City yang lebih baik.

2. Regulasi Pemerintah harus disesuaikan dan diselaraskan dengan inovasi perkembangan teknologi supaya bisa seiring dan sejalan.

3. Perlu adanya evaluasi dari seluruh program Jakarta Smart City yang sudah dijalankan untuk memperbaiki program dan pelayanan kepada masyarakat.

4. Untuk komponen Jakarta Smart City perlu ditambahkan dua komponen lagi yaitu :

a. Smart Service. Menyediakan dan memberikan pelayanan dengan cepat serta memuaskan baik melalui aplikasi smart service yang bisa diakses melalui telepon, email atau pesan singkat. Aplikasi ini masyarakat dapat mengakses berbagai layanan, penyampaian keluhan, permohonan izin hingga layanan gawat darurat.

b. Smart Operation Center Mengelola, menjamin seluruh kinerjanya dengan jaringan telekomunikasi dan infrastruktur IT untuk memberikan kualitas layanan yang tertinggi yang diperlukan kliennya, melalu pusat operasi cerdas mengoperasikan automatic meter infrastruktur mendatang untuk air, gas, limbah dan lain-lain.

\section{DAFTAR PUSTAKA}

Abdul Kadir, (2002). Pengenalan Sistem Informasi. Penerbit: Andi Offset, Yogyakarta.

Agus, I putu, E.P. (2014). Smart city beserta Cloud Computing dan TeknologiTeknologi pendukung lainnya, Penerbit: Informatika, Bandung.

Airaksinen, Miimu, et.al. 2015. Smart City-Research Highlights. Miimu Airaksinen and Matti Kokkala (ed). Grano: VTT Technical Research Centre of Firland Ltd. 
Al-Hader, Mahmoud and Ahmad Rodzi.2009. The Smart City Infrastructure Development and Monitoring. CCSAP, Number 2(11): 87-94.

Bakici, Tuba, Esteve Almiral, and Jonathan Wareham.2013. A Smart City Initiative: the Case of Barcelona. J Knowl Econ (2013). 4:135-148

Batty, Michael, et.al.2012. Understanding Smart Cities: An Integrative Statement \& Guidelines. Official Report of Smart City Mission Transformation on June, 2015

Burhanuddin, 2003 Civil Society \& Demokrasi: Survey tentang Prtisipasi Sosial-Politik Warga Jakarta. Ciputat: Indonesian Insitute for Civil Society (INCIS). hal 49>

Chris Rowley dan Keith Jackson (2012). Manajemen Sumber Daya Manusia. Penerbit: PT. Raja Grafindo Persada, Jakarta.

Dharma Setyawan Salam (2004). Manajemen pemerintahan Indonesia. Penerbit: Djembatan Jakarta

Ghosali, Imam (2001). Aplikasi Multavariate Dengan Program SPSS, Cetakan IV. Penerbit: Badan Penerbit Universitas Diponegoro, Semarang.

Hasibuan H. Malayu (2005). Manajemen Sumber Daya Manusia. Penerbit Bumi Aksara, Jakarta

Hanif Al Fatta.(2007) Analisis dan Perancangan Sistem Informasi, Andi, Yogyakarta

H.A.R Tilaar. Pendidikan, Kebudayaan Dan Masyarakat Madani Indonesia. Bandung : PT Remaja Rosdakarya (Yysn Adikarya IKAPI dan The Ford Foundation), 2002

Iftiyani (2015). Pengaruh Teknologi Smart City Terhadap Kinerja Aparatur Pemerintah Kota Administrasi Jakarta Utara. Skripsi IBM ASMI.

Komaruddin Hidayat dan Azyumari Azra. Demokrasi, Hak Asasi Manusia dan Masyarakat Madani.Jakarta: ICCE UIN Hidayatullah Jakarta dan The Asia Foundation, 2006, hal. 302-325.

M.Dawan Rahardjo. Masyarakat Madani: Agama, Kelas Menengah dan Perubahan Sosial. Jakarta: LP3ES, 1999. hal. xxiii.

Nam,Taewoo and Theresa A.Pardo.2011. Smart City as Urban Innovation: Focusing on Management, Policy, and Context. ICEGOV, September 26-28:185-194.

Qodri Azizy. 2004. Melawan Golbalisasi Reinterpretasi Ajaran Islam: Persiapan SDM dan Terciptanya Masyarakat Madani. (Yogyakarta: Pustaka Pelajar).

Sugiyono (2011). Metode Penelitian Kuantitatif, kualitatif dan R \& D. Penerbit: Alfabeta, Bandung.

Sutanta, Edhy. (2011), Basis Data Dalam Tinjauan Konseptual, Andi, Yogyakarta.

Tata Sutabri, (2014) Analisis Sistem Informasi. Penerbit: CV Andi Offset, OFFSET, Yogyakarta.

\section{Website:}

Jakarta Smart City go.id

Ekonomi Kompas Komp. 